\title{
Procoagulant properties of human MV3 melanoma cells
}

\author{
D.L.A. Geaquinto ${ }^{1}$, R.S. Fernandes ${ }^{1}$, L.G. Lima ${ }^{1}$, C. Barja-Fidalgo ${ }^{2}$ and R.Q. Monteiro ${ }^{1}$ \\ ${ }^{1}$ Instituto de Bioquímica Médica, Centro de Ciências da Saúde, Universidade Federal do Rio de Janeiro, \\ Rio de Janeiro, RJ, Brasil \\ 2Departamento de Farmacologia, Instituto de Biologia, Universidade do Estado do Rio de Janeiro, \\ Rio de Janeiro, RJ, Brasil \\ Correspondence to: R.Q. Monteiro, Instituto de Bioquímica Médica, CCS, UFRJ, Avenida Bauhínia, 400, \\ Ilha do Fundão, 21941-590 Rio de Janeiro, RJ, Brasil \\ Fax: +55-21-2270-8647. E-mail: robsonqm@bioqmed.ufrj.br
}

\begin{abstract}
A correlation between cancer and prothrombotic states has long been described. More recently, a number of studies have focused on the procoagulant mechanisms exhibited by tumor cells. In the present study, we dissected the molecular mechanisms responsible for the procoagulant activity of MV3, a highly aggressive human melanoma cell line. It was observed that tumor cells strongly accelerate plasma coagulation as a result of: i) expression of the blood clotting initiator protein, a tissue factor, as shown by flow cytometry and functional assays (factor Xa formation in the presence of cells and factor VIla), and ii) direct activation of prothrombin to thrombin by cells, as evidenced by hydrolysis of the synthetic substrate, S-2238, and the natural substrate, fibrinogen. This ability was highly potentiated by the addition of exogenous factor Va, which functions as a cofactor for the enzyme factor Xa. In contrast, prothrombin activation was not observed when cells were previously incubated with DEGR-factor Xa, an inactive derivative of the enzyme. Moreover, a monoclonal antibody against bovine factor Xa reduced the prothrombin-converting activity of tumor cells. In conclusion, the data strongly suggest that MV3 cells recruit factor Xa from the culture medium, triggering an uncommon procoagulant mechanism.
\end{abstract}

Key words: MV3 melanoma; Blood clotting; Tissue factor; Thrombin

Research supported by CNPq, FAPERJ, Fundação Universitária José Bonifácio (FUJB), and "Programa Interinstitucional de Ensino, Pesquisa e Extensão em Biologia do Câncer" of Fundação Ary Frauzino para Pesquisa e Controle do Câncer (FAF), and Fundação Educacional Charles Darwin (FECD).

Received May 3, 2007. Accepted November 22, 2007

\section{Introduction}

Blood coagulation involves a series of zymogen activation reactions that are mainly performed by enzymatic complexes consisting of a serine protease, a protein co-factor and membranes containing anionic phospholipids (1). Tissue factor (TF) is a 47-kDa membrane-bound protein that serves as a receptor and co-factor for the enzyme factor VIla (FVIla), with subsequent formation of the extrinsic tenase complex that converts factor $X(F X)$ to $\mathrm{FXa}(2)$. Further recruitment of activated platelets, which expose phosphatidylserine on their membranes, allows the assembly of the intrinsic tenase (FIXa/FVIIla) and prothrombinase ( $\mathrm{FXa} / \mathrm{FVa}$ ) complexes, resulting in additional FX activation and conversion of prothrombin to thrombin, respectively (3).

A correlation between cancer and procoagulant states has been described for more than a century $(4,5)$ and a number of mechanisms have been proposed to explain such observations, including (6): i) increased expression of procoagulant proteins by tumor cells; ii) production of inflammatory cytokines by tumor cells and/or the host with subsequent activation of vascular cells, including platelets, endothelial cells and monocytes; iii) direct tumor-cell interactions also resulting in activation of vascular cells; iv) exposure of procoagulant lipids, in particular phosphatidyl- 
serine, by tumor cells $(7,8)$. Therefore, tumor cells may activate blood clotting by promoting the assembly of procoagulant complexes on their surface (9-11).

Several studies have indicated that coagulation proteins play significant roles in cancer biology. Studies employing cultured cells as well as patient samples have demonstrated a strong correlation between TF expression and an aggressive pattern $(12,13)$. Also, the presence of TF correlates with production of vascular endothelial growth factor and/or increased microvessel density $(13,14)$. Aberrant expression and activation of the coagulation enzyme receptors (proteinase-activated receptors) on tumor cells have also been associated with many aspects of tumor biology including migration, survival and production of angiogenic factors, enzymes and cytokines (15-17).

Melanoma is a highly metastatic cancer, and there is strong evidence that a procoagulant behavior contributes to this aggressive pattern $(18,19)$. MV3 is a human melanoma cell line that has been established after subcutaneous implantation of fragments of a fresh human melanoma metastasis sample in nude mice (20). This cell line is highly tumorigenic and metastatic in nude mice and represents a useful tool for studying the expression and regulation of molecules in human melanoma cells involved in the process of metastasis. In the present study, we demonstrate that MV3 cells display potent procoagulant activity, an ability partially due to the presence of functional TF on MV3 cells. In addition, tumor cells directly activated prothrombin to thrombin, this effect being strongly potentiated by $\mathrm{FVa}$ and significantly inhibited by DEGR-FXa or a monoclonal antibody against $\mathrm{FXa}$.

\section{Material and Methods}

\section{Material}

Human prothrombin was purified according to a previously reported procedure (21). FXa and human fibrinogen were purchased from Calbiochem (USA). Human FVa, FX and monoclonal anti-bovine (ABX-5051) and anti-human (AHX-5050) FX were purchased from Haematological Technologies (USA). According to the manufacturer, an antibody raised against the human protein does not recognize bovine FX. Human FVIla was purchased from American Diagnostica (USA). Chromogenic substrates for FXa (S-2765, N- $\alpha$-benzyloxycarbonyl-D-Arg-Gly-Arg-p-nitroanilide) and thrombin (S-2238, H-D-phenylalanyl-Lpipecolyl-L-arginine-p-nitroaniline dihydrochloride) were purchased from Diapharma. MV3 cells were kindly provided by Dr. C. Marcinkiewicz (Temple University, USA). Ethylenediaminetetraacetic acid (EDTA) and polyethyleneglycol were purchased from Sigma (USA).

\section{Cell culture}

The human melanoma cell line, MV3, was grown at $37^{\circ} \mathrm{C}$ in a humidified $5 \% \mathrm{CO}_{2}$ atmosphere in culture flasks by subconfluent passages in Dulbecco's modified Eagle's medium (DMEM, Gibco-BRL, USA) supplemented with 2 $\mathrm{g} / \mathrm{L}$ HEPES, $60 \mathrm{mg} / \mathrm{L}$ penicillin, $100 \mathrm{mg} / \mathrm{L}$ streptomycin, $2 \mathrm{~g} /$ $L$ sodium bicarbonate. Subconfluent tumor cells were detached with Hank's EDTA buffer ( $0.4 \mathrm{~g} / \mathrm{L}$ potassium chloride, $0.06 \mathrm{~g} / \mathrm{L}$ potassium phosphate monobasic, $8 \mathrm{~g} / \mathrm{L}$ $\mathrm{NaCl}, 0.048 \mathrm{~g} / \mathrm{L}$ sodium phosphate dibasic, $1 \mathrm{~g} / \mathrm{L}$ D-glucose, $350 \mathrm{mg} / \mathrm{L}$ sodium bicarbonate, $1.86 \mathrm{~g} / \mathrm{L}$ EDTA, $\mathrm{pH}$ 7.2), resuspended in DMEM and transferred to another culture flask with DMEM containing $10 \%$ fetal bovine serum.

Procoagulant activity measured by recalcification time

The ability of MV3 melanoma cells to potentiate plasma coagulation was assessed by measuring the recalcification time on an Amelung KC4A coagulometer (Labcon, Germany), using plastic tubes. Fifty microliters of citrated human platelet-poor plasma ( $3.8 \%$ sodium citrate, $1: 9$, v/v) was incubated with $50 \mu \mathrm{L} \mathrm{MV} 3$ cells at $5 \times 10^{3}, 5 \times 10^{4}$, or $5 \times 10^{5}$ cells and suspended in PBS for $1 \mathrm{~min}$ at $37^{\circ} \mathrm{C}$. Plasma clotting was initiated by the addition of $100 \mu \mathrm{L} 12.5$ $\mathrm{mM} \mathrm{CaCl} 2$ and coagulation time was recorded.

\section{Flow cytometric analyses}

Cells grown in culture were resuspended in phosphate buffer containing $1 \% \mathrm{BSA}$ and incubated for $30 \mathrm{~min}$, at $4^{\circ} \mathrm{C}$, with a murine monoclonal antibody against TF (4509, American Diagnostica), that had been directly labeled with the green-fluorescent Alexa Fluor 488 dye using the Alexa Fluor $^{\circledR} 488$ Monoclonal Antibody Labeling Kit (A-20181, Molecular Probes/Invitrogen, USA). After washing to remove unbound antibody, cells were analyzed using a FACScalibur (Becton-Dickinson, USA). Data were analyzed with the BD CellQuest 3.3 software.

\section{FX activation as followed by hydrolysis of chromogenic substrate}

Activation of $\mathrm{FX}$ to $\mathrm{FXa}$ catalyzed by FVIla was performed in $50 \mathrm{mM}$ HEPES, $100 \mathrm{mM} \mathrm{NaCl}, 5 \mathrm{mM} \mathrm{CaCl}_{2}, 1$ $\mathrm{mg} / \mathrm{mL}$ BSA, pH 7.5 (HEPES-BSA buffer), as follows: FVIla $(1 \mathrm{nM})$ was incubated for different times at $37^{\circ} \mathrm{C}$ with MV 3 cells $\left(0\right.$ to $5 \times 10^{4}$ cells $/ \mathrm{mL}$ ) in the presence of $100 \mathrm{nM}$ FX. After the addition of $50 \mu \mathrm{L} 300 \mu \mathrm{M} \mathrm{S}-2765$ prepared in $50 \mathrm{mM}$ Tris- $\mathrm{HCl}, 150 \mathrm{mM} \mathrm{NaCl}, 20 \mathrm{mM}$ EDTA, $1 \mathrm{mg} / \mathrm{mL}$ polyethyleneglycol 6000, pH 7.5 (Tris-EDTA buffer), absorbance at $405 \mathrm{~nm}$ was recorded at $37^{\circ} \mathrm{C}$ for $30 \mathrm{~min}$ at 6$s$ intervals using a Thermomax Microplate Reader (Molecular Devices, USA) equipped with a microplate mixer and 
heating system as described (22). Velocities (mOD/min) obtained in the first minutes of reaction were used to calculate the amount of FXa formed, as compared to a standard curve using known enzyme concentrations. In some experiments, cells were previously incubated with anti-TF antibody (4509, American Diagnostica), before starting the FX activation reaction. Appropriate controls performed in the absence of FVIla showed no significant formation of FXa.

Prothrombin activation as followed by hydrolysis of chromogenic substrate or fibrinogen

Activation of prothrombin to thrombin was performed in $50 \mathrm{mM}$ HEPES, $100 \mathrm{mM} \mathrm{NaCl}, 5 \mathrm{mM} \mathrm{CaCl} 2,1 \mathrm{mg} / \mathrm{mL}$ BSA, pH 7.5 (HEPES-BSA buffer), as follows: $500 \mathrm{nM}$ prothrombin was incubated for different times at $37^{\circ} \mathrm{C}$ with 0 to $5 \times 10^{4}$ cells $/ \mathrm{mL} \mathrm{MV3} \mathrm{cells} \mathrm{in} \mathrm{the} \mathrm{presence} \mathrm{or} \mathrm{absence}$ of $1 \mathrm{nM}$ FVa. After the addition of $50 \mu \mathrm{L} 300 \mu \mathrm{M} \mathrm{S}-2765$ (prepared in Tris-EDTA buffer) or $2 \mathrm{mg} / \mathrm{mL}$ fibrinogen (prepared in HEPES-BSA buffer), absorbance at $405 \mathrm{~nm}$ was recorded at $37^{\circ} \mathrm{C}$ for $60 \mathrm{~min}$ at 6 -s intervals using a Thermomax Microplate Reader (Molecular Devices) as described above. Velocities (mOD/min) obtained in the first minutes of reaction were used to calculate the amount of thrombin formed, as compared to a standard curve using known enzyme concentrations. In some experiments, MV3 cells were pre-incubated with DEGR-FXa (130 nM) overnight or with monoclonal anti-bovine or anti-human FX antibodies $(10 \mu \mathrm{g} / \mathrm{mL})$ for $10 \mathrm{~min}$, before starting the prothrombin activation reaction.

\section{Results}

In order to determine whether MV3 melanoma cells display procoagulant properties, we first tested the effect of these cells on the recalcification time of human plasma. As shown in Figure 1, increasing cell concentrations strongly decreased the coagulation time, demonstrating that these cells display potent procoagulant activity. Previous studies employing other human melanoma cell lines have demonstrated this ability as a result of TF expression $(18,23)$. Accordingly, by means of flow-cytometric analysis using a monoclonal antibody, we demonstrated positive staining for TF on MV3 cells (Figure 2A). Further enzymatic assays showed that TF expressed on MV3 cells is functional. Figure 2 shows that $\mathrm{FXa}$ formation was both FVIla- (Figure 2B) and time-dependent (Figure 2C), indicating the formation of the extrinsic tenase complex. Negligible zymogen activation was observed in the absence of FVIla (Figure $2 \mathrm{C}$ ), possibly indicating that MV3 cells are not able to directly activate FX. In addition, Figure 2D shows that increasing concentrations of a monoclonal anti-TF antibody progressively decreased $\mathrm{FX}$ activation, confirming that this effect is dependent on the presence of the FVIIa co-factor, TF.

In addition to TF expression, other mechanisms have been proposed to explain the procoagulant activity of tumor cells (6). In this context, MV3 cells were able to directly convert prothrombin to thrombin, i.e., in the absence of additional blood clotting proteins in the assay medium (Figure 3, open squares). Remarkably, this ability was strongly potentiated by the addition of the FXa cofactor, FVa (Figure 3, filled squares), suggesting that MV3 cells display previously bound enzyme.

The ability of MV3-generated thrombin to cleave fibrinogen was further evaluated. Figure $4 \mathrm{~A}$ shows that incubation of prothrombin with MV3 cells results in fibrinogen clotting, as detected by increased absorbance at 405 $\mathrm{nm}$. No significant clotting was detected when fibrinogen was incubated only with MV3 cells or prothrombin. As observed with the chromogenic substrate, addition of FVa to the assay medium efficiently potentiated thrombin formation which resulted in a significant decrease of the time for fibrinogen clotting, as compared to curves in the absence of the protein co-factor (Figure 4B).

Finally, to better understand the mechanism of pro-

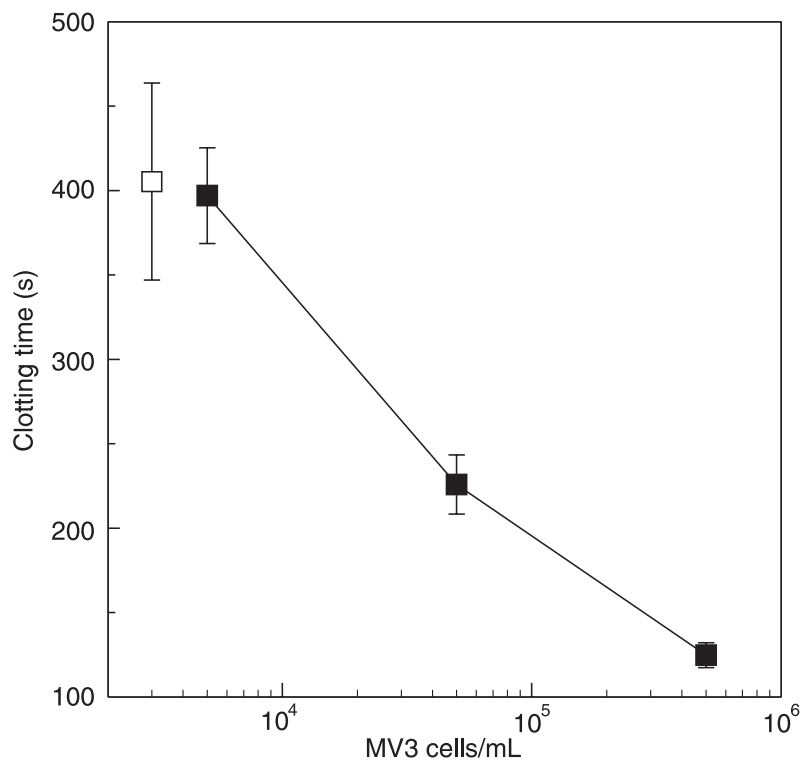

Figure 1. Procoagulant activity of MV3 melanoma cells. MV3 cells (in PBS) at the indicated concentrations were incubated with human plasma followed by recalcification with $12.5 \mathrm{mM}$ $\mathrm{CaCl}_{2}$. Each point represents the mean $\pm \mathrm{SD}$ of three assays. The open square represents controls performed in the absence of cells. 

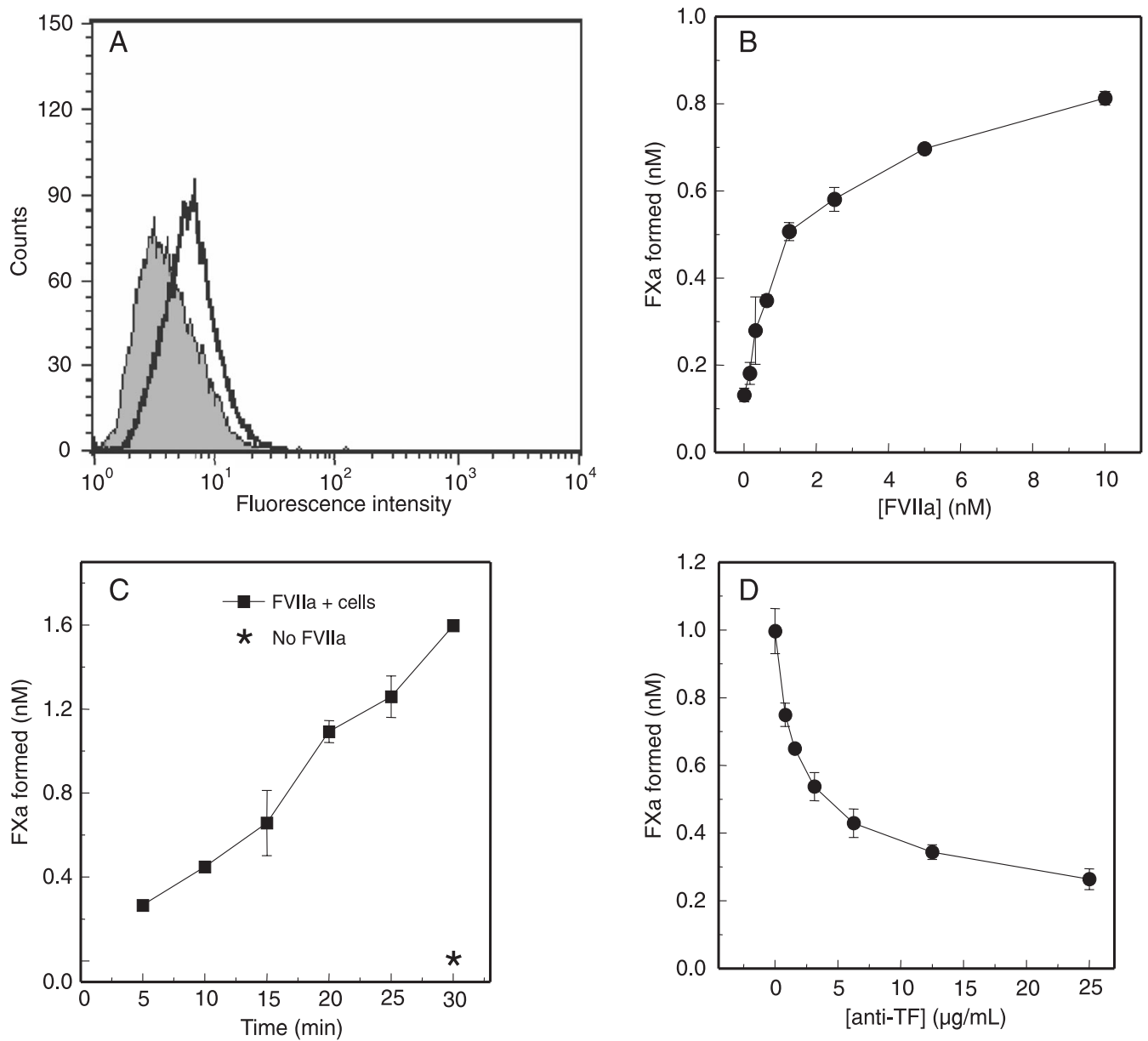

Figure 2. MV3 cells express functional tissue factor (TF) and assemble the extrinsic tenase complex. $A$, Flow-cytometric analysis of TF expression in MV3 melanoma cells. The solid line represents staining with monoclonal anti-TF antibody labeled with greenfluorescent Alexa Fluor 488 dye. The grey region represents control cells with no staining. $B$, FVIla-dependence for activation of $\mathrm{FX}$ $(100 \mathrm{nM})$ in the presence of $5 \times 10^{4}$ cells, after 8 min of reaction. C. Kinetics of the activation of FX (100 nM) in the presence of FVIla $(1 \mathrm{nM})$ and MV3 cells $\left(5 \times 10^{4}\right.$ cells $/ \mathrm{mL}$; squares), or MV3 cells $\left(5 \times 10^{4}\right.$ cells $\left./ \mathrm{mL}\right)$ in the absence of FVIla (asterisk). $D$, Effect of increasing concentrations of monoclonal antibody against human TF on the activation of FX. Each point represents the mean \pm SD of three determinations. FVIla = factor VIIa; FX = factor $\mathrm{X}$.

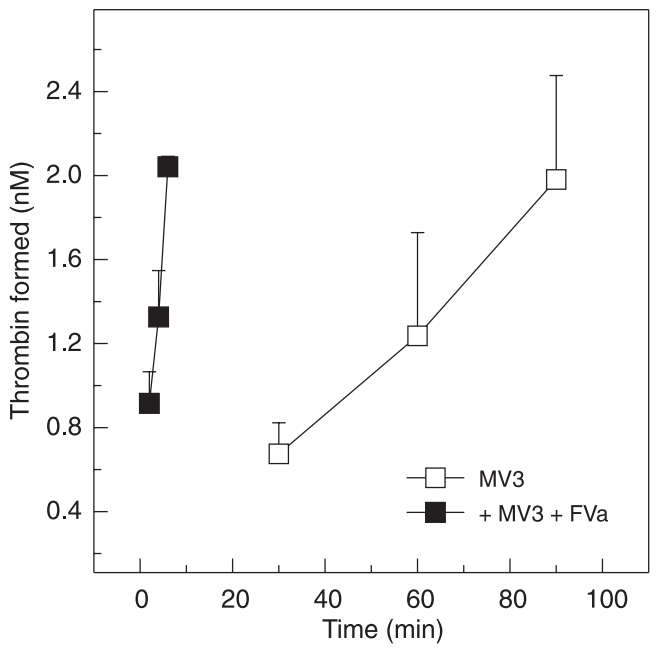

Figure 3. Prothrombin activation by MV3 cells, as detected by S2238 hydrolysis. MV3 cells $\left(5 \times 10^{4}\right.$ cells $\left./ \mathrm{mL}\right)$ were incubated with $0.5 \mu \mathrm{M}$ prothrombin in the absence (open squares) or in the presence (filled squares) of FVa $(1 \mathrm{nM})$. Each point represents the mean $\pm \mathrm{SD}$ of three determinations. $\mathrm{FVa}=$ factor $\mathrm{Va}$. 

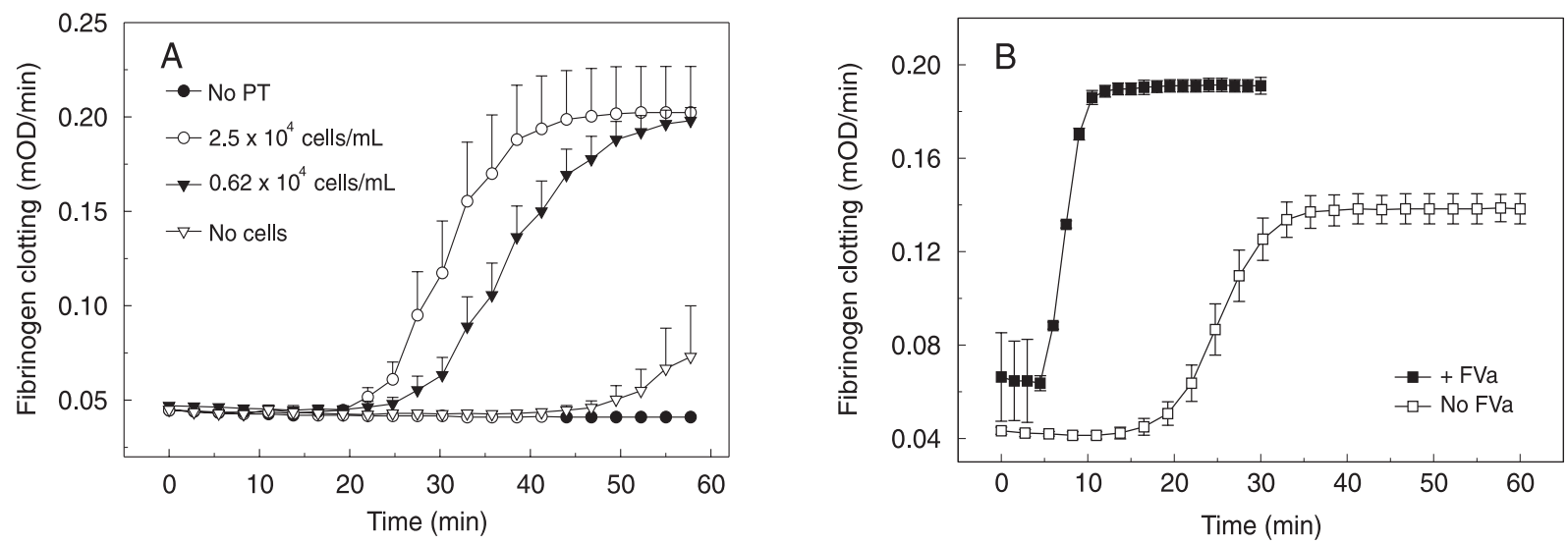

Figure 4. Fibrinogen clotting by MV3-generated thrombin. $A, \mathrm{MV} 3$ cells at the indicated concentrations were incubated with human fibrinogen $(2 \mathrm{mg} / \mathrm{mL}$ ) and $0.5 \mu \mathrm{M}$ prothrombin. Fibrinogen clotting was monitored by the increase in absorbance at $405 \mathrm{~nm}$. The filled circles indicate controls performed in the presence of MV3 cells $\left(5 \times 10^{4} \mathrm{cells} / \mathrm{mL}\right)$ and in the absence of prothrombin (No PT). B, MV3 cells $\left(5 \times 10^{4}\right.$ cells $\left./ \mathrm{mL}\right)$ were incubated with human fibrinogen $(2 \mathrm{mg} / \mathrm{mL})$ and $0.5 \mu \mathrm{M}$ prothrombin in the presence (filled squares) or in the absence (open squares) of FVa $(1 \mathrm{nM})$. Each point represents the mean \pm SD of three determinations. FVa $=$ factor $V a$.
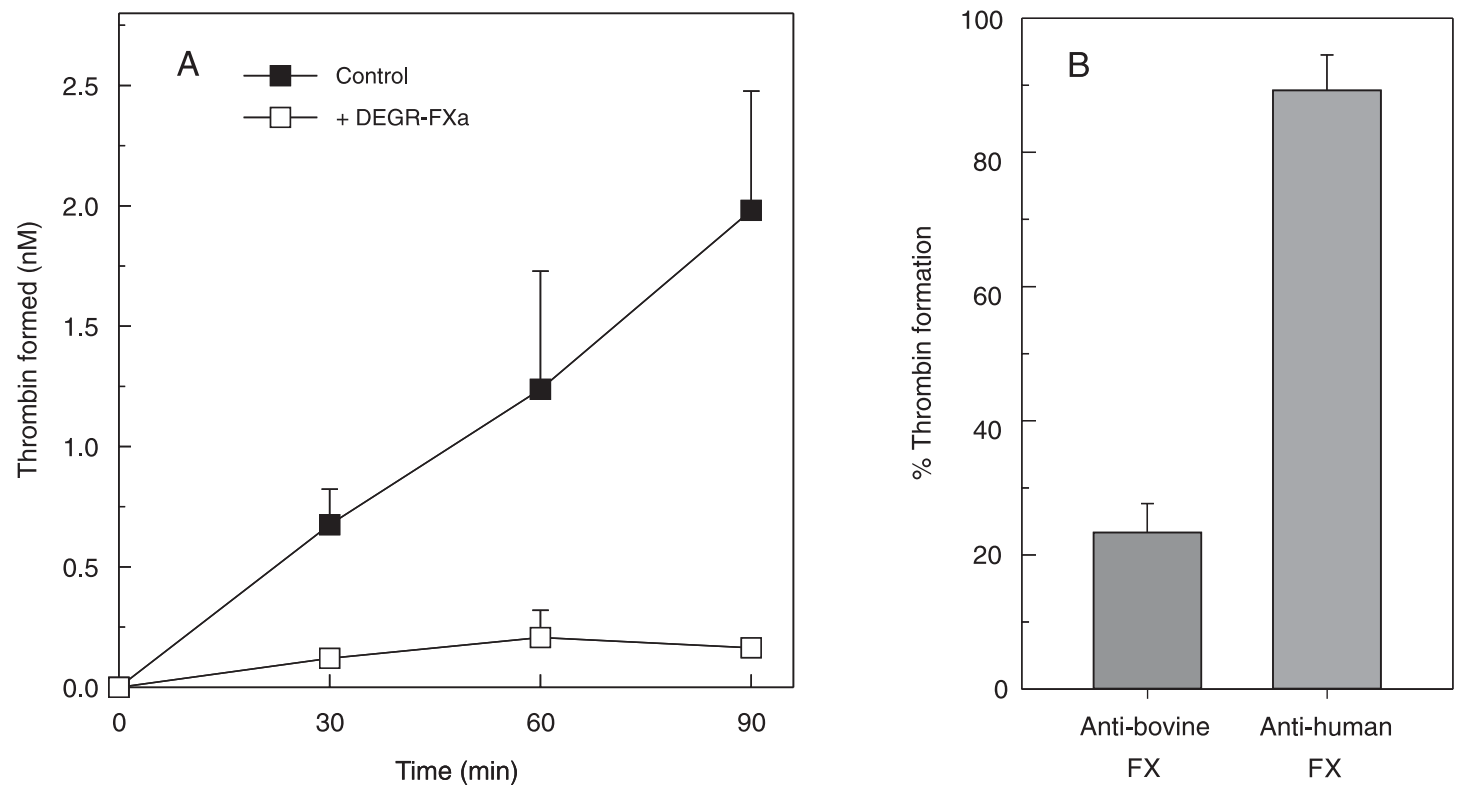

Figure 5. DEGR-FXa and bovine anti-FX (factor X) decrease prothrombin activation by MV3 cells. A, Kinetics of the activation of prothrombin $(0.5 \mu \mathrm{M})$ in the presence of $5 \times 10^{4} \mathrm{MV} 3 \mathrm{cells} / \mathrm{mL}$ cultured overnight in the presence (open squares) or in the absence (filled squares) of $130 \mathrm{nM}$ DEGR-FXa. $B$, Effect of the indicated monoclonal anti-FX antibodies $(10 \mu \mathrm{g} / \mathrm{mL})$ on prothrombin $(0.5 \mu \mathrm{M})$ activation by $5 \times 10^{4} \mathrm{MV} 3$ cells $/ \mathrm{mL}$ after $90 \mathrm{~min}$ of incubation, as determined by S-2238 hydrolysis. Each point represents the mean \pm $\mathrm{SD}$ of three determinations. DEGR-FXa = an inactive derivative of the enzyme.

thrombin activation by MV3, cells were pre-incubated with DEGR-FXa, an inactive FXa derivative, prior to zymogen activation assay. As seen in Figure $5 \mathrm{~A}$, treatment with the inactivated enzyme rendered MV3 cells unable to activate prothrombin. In addition, assays were performed in the presence of specific anti-FX monoclonal antibodies. As seen in Figure 5B, anti-bovine but not anti-human FX significantly decreased zymogen activation. Overall, these data strongly suggest that MV3 cells recruit FXa from the fetal calf serum-enriched culture medium, with this mechanism being, at least in part, responsible for the procoagulant ability of these tumor cells. 


\section{Discussion}

Several lines of evidence indicate that the procoagulant properties of cancer cells play a significant role in tumor biology, with this observation being particularly evident in melanoma. In the present study, we identified two major procoagulant mechanisms in the highly aggressive human melanoma cell line, MV3. These cells express functional TF on their surface as demonstrated by flow cytometric and functional assays. In fact, the presence of TF in melanoma cell lines has been well documented and the levels of protein expression seem to be correlated with the aggressiveness (23). TF levels seem to be also involved in the metastatic potential of melanoma cells, although procoagulant activity is not required for this ability (19). In addition, the production of vascular endothelial growth factor was directly correlated with TF expression in melanoma cell lines, with this property being dependent on the cytoplasmic tail but not on the extracellular domain of the protein (24).

Our data strongly suggest that MV3 cells recruit small amounts of active FXa, resulting in an unusual mechanism of procoagulant activity in which cells directly activate prothrombin to thrombin in the absence of additional exogenous blood clotting factors. In fact the ability of tumor cells to recruit $\mathrm{FXa}$ and promote prothrombin activation has been previously reported for B16-F10 melanoma (10), colon adenocarcinoma (25), human pleural mesothelial cells (26), and others. In the last case, it was reported that

\section{References}

1. Mann KG. Biochemistry and physiology of blood coagulation. Thromb Haemost 1999; 82: 165-174.

2. Mackman N. Role of tissue factor in hemostasis, thrombosis, and vascular development. Arterioscler Thromb Vasc Biol 2004; 24: 1015-1022.

3. Monroe DM, Hoffman M, Roberts HR. Platelets and thrombin generation. Arterioscler Thromb Vasc Biol 2002; 22: 1381-1389.

4. Mandala M, Ferretti G, Cremonesi M, Cazzaniga $M$, Curigliano G, Barni S. Venous thromboembolism and cancer: new issues for an old topic. Crit Rev Oncol Hematol 2003; 48: 65-80.

5. Otten HM, Prins MH. Venous thromboembolism and occult malignancy. Thromb Res 2001; 102: V187-V194.

6. Rickles FR, Falanga A. Molecular basis for the relationship between thrombosis and cancer. Thromb Res 2001; 102: V215-V224.

7. Connor J, Bucana C, Fidler IJ, Schroit AJ. Differentiationdependent expression of phosphatidylserine in mammalian plasma membranes: quantitative assessment of outer-leaflet lipid by prothrombinase complex formation. Proc Natl a number of monoclonal antibodies raised against $\mathrm{FXa}$ impaired the function of tumor cell-bound enzyme, offering a potential means to prevent local thrombin formation (27).

In addition to TF, thrombin seems to play a key role in melanoma progression. Thrombin increases the metastatic potential of B16 melanoma cells in mice $(28,29)$ while the inhibition of the enzyme by hirudin decreases tumor growth, metastasis and seeding into blood (30-32). In fact, a number of thrombin actions in melanoma cells are mediated by the protease-activated receptor (33-35), which requires catalytically active enzyme.

The presence of fibrin in the tumor stroma has been well documented (36) and in fact the cross-linked fibrin provides a provisional matrix that facilitates tumor angiogenesis (37). In this context, TF-induced generation of thrombin with subsequent fibrin deposition is usually referred to as the main clotting-dependent mechanism in tumor progression. Herein we demonstrate that incubation of prothrombin with MV3 cells results in fibrinogen cleavage. As a consequence, tumor cells displaying this ability could support fibrin deposition despite presenting low levels of TF.

\section{Acknowledgments}

We thank Dr. C.R. Carlini (UFRGS) for a careful revision of the manuscript, Dr. Carmen Nogueira (HUCFF/ UFRJ, RJ, Brazil) for providing the human plasma samples, and Ana Lúcia O. Carvalho for technical assistance.
Acad Sci U S A 1989; 86: 3184-3188.

8. Barrowcliffe TW, Fabregas P, Jardi M, Cancelas J, Rabaneda M, Felez J. Procoagulant activity of T lymphoblastoid cells due to exposure of negatively charged phospholipid. Thromb Haemost 2002; 87: 442-449.

9. VanDeWater L, Tracy PB, Aronson D, Mann KG, Dvorak HF. Tumor cell generation of thrombin via functional prothrombinase assembly. Cancer Res 1985; 45: 5521-5525.

10. Kirszberg C, Rumjanek VM, Monteiro RQ. Assembly and regulation of prothrombinase complex on B16F10 melanoma cells. Thromb Res 2005; 115: 123-129.

11. Fernandes RS, Kirszberg C, Rumjanek VM, Monteiro RQ. On the molecular mechanisms for the highly procoagulant pattern of C6 glioma cells. J Thromb Haemost 2006; 4: 1546-1552.

12. Ruf W, Mueller BM. Tissue factor in cancer angiogenesis and metastasis. Curr Opin Hematol 1996; 3: 379-384.

13. Guan M, Jin J, Su B, Liu WW, Lu Y. Tissue factor expression and angiogenesis in human glioma. Clin Biochem 2002; 35: 321-325.

14. Nakasaki T, Wada H, Shigemori C, Miki C, Gabazza EC, 
Nobori T, et al. Expression of tissue factor and vascular endothelial growth factor is associated with angiogenesis in colorectal cancer. Am J Hematol 2002; 69: 247-254.

15. Even-Ram S, Uziely B, Cohen P, Grisaru-Granovsky S, Maoz M, Ginzburg Y, et al. Thrombin receptor overexpression in malignant and physiological invasion processes. Nat Med 1998; 4: 909-914.

16. Belting M, Ahamed J, Ruf W. Signaling of the tissue factor coagulation pathway in angiogenesis and cancer. Arterioscler Thromb Vasc Biol 2005; 25: 1545-1550.

17. Rao LV, Pendurthi UR. Tissue factor-factor VIla signaling. Arterioscler Thromb Vasc Biol 2005; 25: 47-56.

18. Mueller BM, Reisfeld RA, Edgington TS, Ruf W. Expression of tissue factor by melanoma cells promotes efficient hematogenous metastasis. Proc Natl Acad Sci U S A 1992; 89: 11832-11836.

19. Bromberg ME, Konigsberg WH, Madison JF, Pawashe A, Garen A. Tissue factor promotes melanoma metastasis by a pathway independent of blood coagulation. Proc Natl Acad Sci U S A 1995; 92: 8205-8209.

20. van Muijen GN, Jansen KF, Cornelissen IM, Smeets DF, Beck JL, Ruiter DJ. Establishment and characterization of a human melanoma cell line (MV3) which is highly metastatic in nude mice. Int $J$ Cancer 1991; 48: 85-91.

21. Bezeaud A, Denninger MH, Guillin MC. Interaction of human alpha-thrombin and gamma-thrombin with antithrombin III, protein C and thrombomodulin. Eur J Biochem 1985; 153: 491-496.

22. Francischetti IM, Valenzuela JG, Ribeiro JM. Anophelin: kinetics and mechanism of thrombin inhibition. Biochemistry 1999; 38: 16678-16685.

23. Amirkhosravi A, Biggerstaff JP, Warnes G, Francis DA, Francis JL. Determination of tumor cell procoagulant activity by Sonoclot analysis in whole blood. Thromb Res 1996; 84: 323-332.

24. Abe K, Shoji M, Chen J, Bierhaus A, Danave I, Micko C, et al. Regulation of vascular endothelial growth factor production and angiogenesis by the cytoplasmic tail of tissue factor. Proc Natl Acad Sci U S A 1999; 96: 8663-8668.

25. Sakai T, Noguchi M, Kisiel W. Tumor cells augment the factor Xa-catalyzed conversion of prothrombin to thrombin. Haemostasis 1990; 20: 125-135.
26. Kumar A, Koenig KB, Johnson AR, Idell S. Expression and assembly of procoagulant complexes by human pleural mesothelial cells. Thromb Haemost 1994; 71: 587-592.

27. Kumar A, Koenig KB, Johnson AR, Fair DS, Idell S. Inhibition of factor Xa-mediated procoagulant activity of human lung fibroblasts and pleural mesothelial cells. Eur Respir J 1995; 8: 2038-2045.

28. Nierodzik ML, Plotkin A, Kajumo F, Karpatkin S. Thrombin stimulates tumor-platelet adhesion in vitro and metastasis in vivo. J Clin Invest 1991; 87: 229-236.

29. Wojtukiewicz MZ, Tang DG, Ciarelli JJ, Nelson KK, Walz DA, Diglio CA, et al. Thrombin increases the metastatic potential of tumor cells. Int J Cancer 1993; 54: 793-806.

30. Esumi N, Fan D, Fidler IJ. Inhibition of murine melanoma experimental metastasis by recombinant desulfatohirudin, a highly specific thrombin inhibitor. Cancer Res 1991; 51: 4549-4556

31. Hu L, Lee M, Campbell W, Perez-Soler R, Karpatkin S. Role of endogenous thrombin in tumor implantation, seeding, and spontaneous metastasis. Blood 2004; 104: 2746-2751.

32. Im JH, Fu W, Wang H, Bhatia SK, Hammer DA, Kowalska $\mathrm{MA}$, et al. Coagulation facilitates tumor cell spreading in the pulmonary vasculature during early metastatic colony formation. Cancer Res 2004; 64: 8613-8619.

33. Nierodzik ML, Chen K, Takeshita K, Li JJ, Huang YQ, Feng $X S$, et al. Protease-activated receptor 1 (PAR-1) is required and rate-limiting for thrombin-enhanced experimental pulmonary metastasis. Blood 1998; 92: 3694-3700.

34. Tellez C, Bar-Eli M. Role and regulation of the thrombin receptor (PAR-1) in human melanoma. Oncogene 2003; 22: 3130-3137.

35. Shi X, Gangadharan B, Brass LF, Ruf W, Mueller BM. Protease-activated receptors (PAR1 and PAR2) contribute to tumor cell motility and metastasis. Mol Cancer Res 2004; 2: 395-402.

36. Nagy JA, Brown LF, Senger DR, Lanir N, Van de Water L, Dvorak AM, et al. Pathogenesis of tumor stroma generation: a critical role for leaky blood vessels and fibrin deposition. Biochim Biophys Acta 1989; 948: 305-326.

37. Fernandez PM, Patierno SR, Rickles FR. Tissue factor and fibrin in tumor angiogenesis. Semin Thromb Hemost 2004; 30: 31-44. 